ОМ. Ю. НИЧИТАЙЛО, О. П. КОНДРАТЮК, Ю. О. ХІЛЬКО, П. В. ОГОРОДНІК, А. Г. ДЕЙНІЧЕНКО, В. А. КОНДРАТЮК, Н. А. ЄРМАК, Т. А. ЮСУПОВ

\title{
Динаміка показників гепатодепресивного синдрому у хворих із механічною жовтяницею пухлинного генезу після ендоскопічної і лапароскопічної паліативної декомпресії загальної жовчної протоки
}

\begin{abstract}
Мета роботи з’ясувати динаміку показників гепатодепресивного синдрому у хворих із механічною жовтяницею пухлинного генезу після ендоскопічної і лапароскопічної паліативної декомпресії загальної жовчної протоки.

Матеріали і методи. Під спостереженням в період з 2011 до 2017 р. перебували 48 пацієнтів, в яких внаслідок комплексного обстеження виявили інкурабельні пухлини на тлі вираженої механічної жовтяниці. Усім хворим виконано паліативну декомпресію загальної жовчної протоки: 30 пацієнтів - із застосуванням ендоскопічних методів; 18 пацієнтів - із використанням лапароскопічної гепатикоєюностомії. Кожну підгрупу рандомізували за віком, статтю, тривалістю жовтяничного періоду та основними біохімічними показниками, визначеними до операції. Пацієнти перебували під спостереженням протягом 6 міс. після декомпресії. До операції, через 1, 7 і 14 діб, а також 3 і 6 міс. у пацієнтів визначали маркери гепатодепресивного синдрому: протромбіновий час, вміст загального білка й альбумінів у сироватці крові за загальновідомими методами.

Результати досліджень та їх обговорення. Лапароскопічна декомпресія загальної жовчної протоки шляхом формування гепатикоєюноанастомозу порівняно з ендоскопічними методами супроводжується швидшим відновленням функціонального стану печінки, що проявляється сталим зниженням протромбінового часу індексу INR i збільшенням вмісту в сироватці крові загального білка та альбумінів через 3-6 міс. після декомпресії. На тлі ендоскопічної декомпресії в цей період протромбіновий час і індекс INR статистично вірогідно більші, вміст у сироватці крові загального білка і альбумінів менший, порівняно з лапароскопічною декомпресією. Через 3-6 міс. після втручання за умов ендоскопічної декомпресії показники гепатодепресивного синдрому суттєво погіршуються, що пов’язано з розвитком у 30 \% пацієнтів ускладнень.
\end{abstract}

Ключові слова: лапароскопічний гепатикоєюноанастомоз; механічна жовтяниця; періампулярна пухлина; гепатодепресивний синдром.

Постановка проблеми і аналіз останніх досліджень та публікацій. Останнім часом спостерігається зростання частоти злоякісних новоутворень органів шлунково-кишкового тракту. Серед них від 1 до 15 \% випадків становлять пухлини біліопанкреатодуоденальної зони [1, 2].

Щорічно у США виявляють до 25 тис. нових випадків періампулярних пухлин [3]. В Японії середня частота раку цієї локалізації спостерігається у 6,6 осіб на 100 тис. населення [4]. Частота виникнення цих пухлин збільшується після 55 років, досягаючи максимуму до 70 років [5].

Основним клінічним проявом періампулярних пухлини є блокада відтоку жовчі з розвитком синдрому механічної жовтяниці (МЖ) [6]. У 75-95 \% випадків МЖ може бути першою ознакою захворювання і свідчити про його інкурабельність [6, 7], оскільки проявляється на пізніх стадіях захворювання, коли радикальні втручання вже малоймовірні.

Головним напрямком допомоги таким хворих $€$ проведення паліативної декомпресії загальної жовчної протоки. Останнім часом для декомпресії жовчних шляхів використовують малоінвазивні ендоскопічні методи, які включають транспапілярне стентування, супрапапілярну холедо- ходуоденостомію та ендоскопічну папілектомію $[8,9]$.

Як паліативний метод ендобіліарне стентування $є$ пріоритетним методом, проте протягом 3-6 міс. у 20-28 \% супроводжується ускладненнями і вимагає реінтервенції, яка на тлі прогресування основного захворювання може бути фатальною.

Лапароскопічна гепатикоєюностомія $€$ ефективною альтернативою ендоскопічним паліативним методам декомпресії загальної жовчної протоки [10]. Використання лапароскопічного способу дозволяє детально візуалізувати операційну зону протягом усього втручання. Це забезпечує більш якісне виконання всіх маніпуляцій, зменшуючи крововтрату.

Дренування загальної жовчної протоки усуває холестаз - основну причину розвитку печінкової недостатності. Однак порівняльний вплив ендоскопічної і лапароскопічної паліативної декомпресії на прояви печінкової недостатності, зокрема на показники гепатодепресивного синдрому вивчено недостатньо, що унеможливлює об'єктивний підхід до вибору методики паліативної декомпресії.

Мета роботи: з'ясувати динаміку показників гепатодепресивного синдрому у хворих із механічною жовтяницею пухлинного генезу після 
ендоскопічної і лапароскопічної паліативної декомпресії загальної жовчної протоки.

Матеріали і методи. Під спостереженням у Національному інституті хірургії та трансплантології імені О. О. Шалімова НАМН України за період з 2011 до 2017 р. перебували 48 пацієнтів із періампулярними пухлинами. Серед них чоловіків було 32 особи (66,7 \%), жінок - 16 осіб (33,3 \%). Середній вік становив $(63,7 \pm 1,5)$ року. Завдяки комплексному обстеженню, яке включало біохімічний аналіз крові та коагулограму, дослідження рівня пухлинних маркерів в крові, ультразвукову діагностику органів черевної порожнини та заочеревного простору, фіброгастродуоденоскопію, комп’ютерну томографію, встановлено інкурабельні пухлини на тлі вираженої МЖ. Середня тривалість МЖ становила $(22,1 \pm 1,3)$ дня. Усім хворим виконано паліативну декомпресію загальної жовчної протоки: 30 пацієнтів - із застосуванням ендоскопічних методів; 18 пацієнтів - 3 використанням лапароскопічної гепатикоєюностомії. Кожну підгрупу рандомізували за віком, статтю, тривалістю жовтяничного періоду та основними біохімічними показниками, визначеними до операції.

Пацієнтів спостерігали протягом 6 міс. після декомпресії. До операції, через 1, 7 і 14 діб, а також 3 i 6 міс. у пацієнтів визначали маркери гепатодепресивного синдрому: протромбіновий час, вміст загального білка та альбумінів у сироватці крові за загальновідомими методами.

Отримані цифрові дані піддавали статистичному аналізу. Відмінності між групами порівнян- ня оцінювали з використанням непараметричного критерію Манна-Уїтні.

Результати досліджень та їх обговорення. На першому етапі нашої роботи, вивчаючи ефективність ендоскопічної і лапароскопічної паліативної декомпресії загальної жовчної протоки, ми досліджували вміст загального і кон'югованого білірубіну в сироватці крові, які є одними з основних індикаторів функціонального стану печінки в клініці.

Величина досліджуваних показників при госпіталізації у групах пацієнтів із подальшою паліативною ендоскопічною і лапароскопічною декомпресією (табл. 1, 2) була практично однакова ( $>0,05)$, що вказує на репрезентативність відібраних груп порівняння за тяжкістю холестазу.

У динаміці післяопераційного періоду вміст у сироватці крові загального білірубіну в пацієнтів з ендоскопічною декомпресією поступово знижувався (табл. 1) і $з 7$ доби ставав статистично вірогідно меншим, ніж у вихідному стані (на 74,9%, р<0,05). У подальшому показник продовжував знижуватися й через 14 діб досягав свого мінімального рівня й був меншим, ніж при госпіталізації на 89,2 \% (p<0,05) та на 57,0 \% порівняно 3 попереднім терміном спостереження ( $<0,05)$. Проте через 3 міс. вміст у сироватці крові загального білірубіну починав зростати й став у 2,63 раза більшим, ніж у попередній термін спостереження $(\mathrm{p}<0,05)$. Через 6 міс. показник продовжував зростали й на 65,1 \% перевищував рівень 3 міс. спостереження $(\mathrm{p}<0,05)$. У цей термін

Таблиця 1. Вміст загального білірубіну в сироватці крові (мкмоль· ${ }^{-1}$ ) після ендоскопічної і лапароскопічної паліативної декомпресії загальної жовчної протоки при механічній жовтяниці пухлинного генезу, Me (QL; QA) - медіана (нижній і верхній квартилі)

\begin{tabular}{|c|c|c|c|c|c|c|}
\hline \multirow{2}{*}{ Група хворих } & \multirow{2}{*}{$\begin{array}{c}\text { При } \\
\text { госпіталізації }\end{array}$} & \multicolumn{5}{|c|}{ Термін обстеження після операції } \\
\hline & & 1 доба & 7 діб & 14 діб & 3 місяці & 6 місяців \\
\hline $\begin{array}{l}\text { Ендоскопічна } \\
\text { декомпресія }(\mathrm{n}=30)\end{array}$ & $\begin{array}{c}339,0 \\
(233,0 ; \\
404,0)\end{array}$ & $\begin{array}{c}311,0 \\
(211,5 ; \\
376,0)\end{array}$ & $\begin{array}{l}85,0^{*} \\
(55,0 ; \\
106,7)\end{array}$ & $\begin{array}{l}36,5^{*} \\
(23,4 ; \\
42,8)\end{array}$ & $\begin{array}{l}96,0^{*} \\
(49,5 ; \\
106,0)\end{array}$ & $\begin{array}{l}158,5^{*} \\
(89,8 ; \\
212,8)\end{array}$ \\
\hline \multicolumn{2}{|c|}{$\mathrm{p}_{1}$} & - & 1д & 1 д,7д & 1д,14д & 1д,7д,14д,3м \\
\hline $\begin{array}{l}\text { Лапароскопічна } \\
\text { декомпресія }(n=18)\end{array}$ & $\begin{array}{c}330,0 \\
(245,5 ; \\
380,3)\end{array}$ & $\begin{array}{c}304,0 \\
(219,5 ; \\
354,3)\end{array}$ & $\begin{array}{l}78,0^{*} \\
(66,8 ; \\
91,2)\end{array}$ & $\begin{array}{l}31,5^{*} \\
(27,0 ; \\
36,8)\end{array}$ & $\begin{array}{l}20,9^{*} \\
(18,1 ; \\
24,6)\end{array}$ & $\begin{array}{l}22,5^{*} \\
(19,5 ; \\
26,5)\end{array}$ \\
\hline \multicolumn{2}{|c|}{$\mathrm{p}_{2}$} & - & $1 д$ & 1 1д,7д & 1д,7д & $1 д, 7 д$ \\
\hline $\mathrm{p}$ & $>0,05$ & $>0,05$ & $>0,05$ & $>0,05$ & $<0,05$ & $<0,05$ \\
\hline
\end{tabular}

Примітки. Тут і в інших таблицях:

1. p - вірогідність відмінностей між групами пацієнтів, яким виконували ендоскопічну і лапароскопічну паліативну декомпресію;

2. * - відмінності стосовно доопераційного періоду статистично вірогідні $(\mathrm{p}<0,05)$;

3. $\mathrm{p}_{1}$ - вірогідність відмінностей порівняно з попередніми термінами спостереження при ендоскопічній декомпресії;

4. $\mathrm{p}_{2}$ - вірогідність відмінностей порівняно з попередніми термінами спостереження при лапароскопічній декомпресії;

5. 1д,7д,14д,3м - відмінності стосовно 1, 7 і 14 доби, а також 3 міс. після операції статистично вірогідні (p<0,05). 
Таблиця 2. Вміст кон'югованого білірубіну в сироватці крові (мкмоль·л ${ }^{-1}$ ) після ендоскопічної і лапароскопічної паліативної декомпресії загальної жовчної протоки при механічній жовтяниці пухлинного генезу, Me (QL; QA) - медіана (нижній і верхній квартилі)

\begin{tabular}{|c|c|c|c|c|c|c|}
\hline \multirow{2}{*}{ Група хворих } & \multirow{2}{*}{$\begin{array}{c}\text { При } \\
\text { госпіталізації }\end{array}$} & \multicolumn{5}{|c|}{ Термін обстеження після операції } \\
\hline & & 1 доба & 7 діб & 14 діб & 3 місяці & 6 місяців \\
\hline $\begin{array}{l}\text { Ендоскопічна } \\
\text { декомпресія }(n=30)\end{array}$ & $\begin{array}{c}211,9 \\
(156,1 ; \\
249,3)\end{array}$ & $\begin{array}{c}180,4 \\
(122,7 ; \\
211,4)\end{array}$ & $\begin{array}{l}72,5^{*} \\
(44,8 ; \\
85,7)\end{array}$ & $\begin{array}{l}30,0^{*} \\
(18,5 ; \\
35,4)\end{array}$ & $\begin{array}{l}61,5^{*} \\
(36,6 \\
77,8)\end{array}$ & $\begin{array}{l}111,6^{*} \\
(64,2 ; \\
147,9)\end{array}$ \\
\hline \multicolumn{2}{|c|}{$\mathrm{p}_{1}$} & - & 1д & $1 д, 7$ д & $1 д, 14 д$ & 1д,7д,14д,Зм \\
\hline $\begin{array}{l}\text { Лапароскопічна } \\
\text { декомпресія }(n=18)\end{array}$ & $\begin{array}{c}197,2 \\
(160,0 ; \\
222,2)\end{array}$ & $\begin{array}{c}174,4 \\
(131,7 ; \\
206,3)\end{array}$ & $\begin{array}{l}74,2^{*} \\
(56,0 ; \\
87,7)\end{array}$ & $\begin{array}{l}25,1^{*} \\
(18,9 ; \\
29,6)\end{array}$ & $\begin{array}{c}14,3^{*} \\
(10,4 ; \\
17,1)\end{array}$ & $\begin{array}{c}8,1^{*} \\
(6,3 ; \\
9,7)\end{array}$ \\
\hline \multicolumn{2}{|c|}{$\mathrm{p}_{2}$} & - & $1 д$ & 1д,7д & $1 д, 7 д$ & 1д,7д,14д,3м \\
\hline $\mathrm{p}$ & $>0,05$ & $>0,05$ & $>0,05$ & $>0,05$ & $<0,05$ & $<0,05$ \\
\hline
\end{tabular}

показник досягав 46,6 \% від рівня, зафіксованого при госпіталізації.

Після лапароскопічної декомпресії показник теж ставав меншим порівняно з рівнем при госпіталізації. Через 7 діб відмінності порівняно з вихідним станом були статистично вірогідними (на 76,4 \%, p<0,05). Через 14 діб показник становив 9,5 \% від вихідного рівня $(\mathrm{p}<0,05)$ й залишався на практично такому ж рівні до 6 міс. спостереження ( $>0,05)$.

Порівняння обох груп пацієнтів, яким виконувалися різні типи паліативних втручань, показало (табл. 3), що до 14 доби післяопераційного періоду вміст у сироватці крові загального білірубіну практично не відрізнявся ( $>0,05)$. Проте через 3 i 6 міс. спостереження у групі пацієнтів, яким виконували лапароскопічну декомпресію, показник ставав істотно меншим, ніж у групі пацієнтів з ендоскопічною декомпресією (відповідно у 4,59 і 7,04 раза, $\mathrm{p}<0,05)$.

У свою чергу, вміст у сироватці крові кон'югованого білірубіну при різних видах паліативної декомпресії жовчних шляхів теж знижувався (див. табл. 2). Після ендоскопічної декомпресії показник вже через 7 діб ставав меншим від рівня, встановленого на час госпіталізації (на $65,8 \%, p<0,05)$ і залишався статистично вірогідно меншим протягом усього терміну спостереження (через 14 діб - на 85,8 \%, р<0,05; через 3 міс. - на 71,0 \%, p<0,05; через 6 міс. - на 47,3 \%, $\mathrm{p}<0,05)$.

Після лапароскопічної декомпресії вміст у сироватці крові кон'югованого білірубіну теж, починаючи 37 доби з моменту госпіталізації, ставав статистично вірогідно меншим, ніж у вихідному стані (на 62,4 \%, p<0,05). В подальшому показник продовжував знижуватися й через 14 діб був меншим від рівня при госпіталізації на 87,3 \% $(\mathrm{p}<0,05)$, через 3 міс. - на 92,7 \% $(\mathrm{p}<0,05)$. Через
6 міс. показник становив лише 4,1 \% від рівня при госпіталізації $(\mathrm{p}<0,05)$.

Порівняння дослідних груп показало (див. табл. 2), що до 14 доби після оперативних втручань істотних відмінностей між групами порівняння за вмістом у сироватці крові кон’югованого білірубіну не спостерігалося (p>0,05), проте через 3 i 6 міс. величина досліджуваного показника за умов паліативної лапароскопічної декомпресії була меншою, ніж після ендоскопічної (відповідно на 76,7 і 92,7 \%, p<0,05).

Аналіз динаміки вміст кон'югованого білірубіну після застосування різних паліативних втручань показав, що до 14 доби післяопераційного періоду показник обох групах знижувався і ставав статистично вірогідно меншим, порівняно 3 попередніми термінами спостереження $(\mathrm{p}<0,05)$. Проте в подальшому на тлі ендоскопічної декомпресії спостерігали істотне зростання вмісту кон’югованого білірубіну в сироватці крові. Через 3 міс. показник у 2,05 раза ставав більшим, ніж через 14 діб $(\mathrm{p}<0,05)$, через 6 міс. - на 81,5 \% більшим, ніж у попередній термін спостереження $(\mathrm{p}<0,05)$. Водночас після застосування лапароскопічних методів декомпресії, вміст у сироватці крові кон’югованого білірубіну продовжував зменшуватися. Так, через 3 міс. показник ставав на 40,4 \% меншим, ніж через 14 діб ( $<<0,05)$, через 6 міс. - на 43,4 \% меншим, ніж через 3 міс. $(\mathrm{p}<0,05)$.

Отримані результати вказують на те, що за динамікою вмісту загального і кон'югованого білірубіну в сироватці крові ефективність декомпресії жовчовивідних шляхів за умов використання лапароскопічної й ендоскопічної технології до 14 доби після операції практично однакова. Величини наведених показників суттєво зменшуються порівняно з доопераційним станом, проте між групами, в яких застосовували різні методи де- 
компресії, практично не відрізняються. Проте через 3 і 6 міс. після операції вміст у сироватці крові загального і кон'югованого білірубіну характеризується статистично вірогідним зростанням, як після лапароскопічних втручань, навпаки, зменшенням, що вказує на істотну перевагу лапароскопічного методу над ендоскопічним.

Важливу інформацію про функціональний стан печінки, зокрема ії синтетичну функцію, дають показники зсідання крові, вміст у сироватці крові альбумінів і загального білка.

Порівняння груп пацієнтів, у яких виконували паліативну ендоскопічну і лапароскопічну декомпресію загальної жовчної протоки, за показниками гепатодепресивного синдрому до операції (табл. 3-5) показало, що в цей термін за величиною протромбінового часу, вмісту загальних білків та альбумінів у сироватці крові статистично значущих відмінностей не спостерігали $(\mathrm{p}>0,05)$. Отримані результати дали підставу вважати, що ступінь ураження паренхіми печінки в групах порівняння був практично однаковим.

Аналіз величини протромбінового часу показав (див. табл. 3), що після проведення ендоскопічної декомпресії показник знижувався й, починаючи 37 доби після втручання, ставав статистично вірогідно менший, ніж при госпіталізації (на $12,0 \%, \mathrm{p}<0,05)$. Через 14 діб показник був менший від рівня при госпіталізації на $14,0 \%(\mathrm{p}<0,05)$, через 3 міс. - на 12,0\% $(\mathrm{p}<0,05)$, через 6 міс. - на $10,0 \%(\mathrm{p}<0,05)$.

Після лапароскопічної декомпресії протромбіновий час теж ставав істотно меншим, ніж при госпіталізації, через 7 діб - на 12,5 \% (p<0,05). В подальшому показник продовжував залишатися меншим, від вихідного рівня: через 14 діб - на 20,8 \% ( $<<0,05)$, через 3 міс. - на 29,2 \% ( $<0,05)$, через 6 міс. - на 25,0 \% $(\mathrm{p}<0,05)$.
Порівняння протромбінового часу між групами, в яких виконували паліативну ендоскопічну і лапароскопічну декомпресію загальної жовчної протоки, показало, що вже через 7 діб величина досліджуваного показника у групі пацієнтів з лапароскопічної декомпресію була статистично вірогідно меншою, ніж з ендоскопічною $(\mathrm{p}<0,05)$. Ця закономірність зберігалася до 6 міс. спостереження.

Аналіз динаміки протромбінового часу показав, що його величина до 14 доби після ендоскопічної декомпресії зменшувалася, що виявилося статистично вірогідним порівняно з показником першої доби спостереження ( $<00,05)$.

У подальшому величина протромбінового часу поступово зростала й через 6 міс. після втручання ставала статистично вірогідно більшою, ніж через 14 діб $(\mathrm{p}<0,05)$, проте не досягала рівня контролю (p>0,05). Після лапароскопічного втручання величина протромбінового часу знижувалася до 3 міс. спостереження. В цей термін показник був статистично вірогідно меншим, ніж через 1, 7 і 14 діб $(\mathrm{p}<0,05)$. Через 6 міс. показник зростав, що було статистично вірогідним, порівняно $з$ 3 міс. (p<0,05), проте продовжував залишатися істотно меншим, ніж через 1 і 7 діб після операції $(\mathrm{p}<0,05)$.

Важливе діагностичне значення у розумінні функціональної спроможності печінки має визначення індексу INR. Це стандарт визначення стану системи згортання крові, який не залежить від способу визначення протромбінового часу і чутливості реактивів, що застосовуються в лабораторіях.

Дослідження показали (див. табл. 4), що при госпіталізації у групах хворих із механічною жовтяницею пухлинного генезу величина індексу INR була практично однаковою (p>0,05). Після проведення паліативних втручань у групі пацієнтів,

Таблиця 3. Протромбіновий час (c) після ендоскопічної і лапароскопічної паліативної декомпресії загальної жовчної протоки при механічній жовтяниці пухлинного генезу, Me (QL; QA) - медіана (нижній і верхній квартилі)

\begin{tabular}{|c|c|c|c|c|c|c|}
\hline \multirow{2}{*}{ Група хворих } & \multirow{2}{*}{$\begin{array}{c}\text { При } \\
\text { госпіталізації }\end{array}$} & \multicolumn{5}{|c|}{ "Термін обстеження після операції } \\
\hline & & 1 доба & 7 діб & 14 діб & 3 місяці & 6 місяців \\
\hline $\begin{array}{l}\text { Ендоскопічна } \\
\text { декомпресія }(\mathrm{n}=30)\end{array}$ & $\begin{array}{l}25,0 \\
(23,0 ; \\
26,0)\end{array}$ & $\begin{array}{c}26,0 \\
(24,0 ; \\
26,8)\end{array}$ & $\begin{array}{l}22,0^{*} \\
(20,3 ; \\
24,0)\end{array}$ & $\begin{array}{l}21,5^{*} \\
(20,0 ; \\
23,8)\end{array}$ & $\begin{array}{l}22,0^{*} \\
(19,3 ; \\
24,0)\end{array}$ & $\begin{array}{l}22,5^{*} \\
(20,3 ; \\
25,0)\end{array}$ \\
\hline \multicolumn{2}{|c|}{$\mathrm{p}_{1}$} & - & $1 д$ & $1 д$ & $1 д$ & 1д,14д \\
\hline $\begin{array}{l}\text { Лапароскопічна } \\
\text { декомпресія }(n=18)\end{array}$ & $\begin{array}{l}24,0 \\
(22,3 ; \\
26,0)\end{array}$ & $\begin{array}{c}24,5 \\
(24,0 ; \\
26,0)\end{array}$ & $\begin{array}{c}21,0^{*} \\
(20,0 ; \\
22,0)\end{array}$ & $\begin{array}{c}19,0^{*} \\
(18,0 ; \\
19,8)\end{array}$ & $\begin{array}{c}17,0^{*} \\
(16,0 ; \\
18,0)\end{array}$ & $\begin{array}{c}18,0^{*} \\
(16,3 ; \\
18,8)\end{array}$ \\
\hline \multicolumn{2}{|c|}{$\mathrm{p}_{2}$} & - & $1 д$ & 1 д & 1д,7д,14д & $1 д, 7 д, 3 м$ \\
\hline $\mathrm{p}$ & $>0,05$ & $>0,05$ & $<0,05$ & $<0,05$ & $<0,05$ & $<0,05$ \\
\hline
\end{tabular}


Таблиця 4. Величина індексу INR (ум. од.) після ендоскопічної і лапароскопічної паліативної декомпресії загальної жовчної протоки при механічній жовтяниці пухлинного генезу, Me (QL; QA) - медіана (нижній і верхній квартилі)

\begin{tabular}{|c|c|c|c|c|c|c|}
\hline \multirow{2}{*}{ Група хворих } & \multirow{2}{*}{$\begin{array}{c}\text { При } \\
\text { госпіталізації }\end{array}$} & \multicolumn{5}{|c|}{ Термін обстеження після операції } \\
\hline & & 1 доба & 7 діб & 14 діб & 3 місяці & 6 місяців \\
\hline $\begin{array}{l}\text { Ендоскопічна } \\
\text { декомпресія (n=30) }\end{array}$ & $\begin{array}{c}1,48 \\
(1,36 ; \\
1,54)\end{array}$ & $\begin{array}{c}1,47 \\
(1,42 ; \\
1,54)\end{array}$ & $\begin{array}{c}1,37 \\
(1,30 ; \\
1,48)\end{array}$ & $\begin{array}{c}1,32^{*} \\
(1,23 ; \\
1,47)\end{array}$ & $\begin{array}{c}1,39 \\
(1,31 ; \\
1,50)\end{array}$ & $\begin{array}{c}1,41 \\
(1,36 ; \\
1,48)\end{array}$ \\
\hline \multicolumn{2}{|l|}{$\mathrm{p}_{1}$} & - & - & 1д & - & 14д \\
\hline $\begin{array}{c}\text { Лапароскопічна } \\
\text { декомпресія }(n=18)\end{array}$ & $\begin{array}{c}1,50 \\
(1,39 ; \\
1,63)\end{array}$ & $\begin{array}{c}1,48 \\
(1,37 ; \\
1,60)\end{array}$ & $\begin{array}{c}1,37^{*} \\
(1,32 ; \\
1,42)\end{array}$ & $\begin{array}{c}1,31^{*} \\
(1,29 ; \\
1,33)\end{array}$ & $\begin{array}{c}1,25^{*} \\
(1,23 ; \\
1,28)\end{array}$ & $\begin{array}{c}1,24^{*} \\
(1,20 ; \\
1,27)\end{array}$ \\
\hline \multicolumn{2}{|l|}{$\mathrm{P}_{2}$} & - & $1 д$ & 1д,7д & 1д,7д,14д & 1д,7д,14д \\
\hline $\mathrm{p}$ & $>0,05$ & $>0,05$ & $>0,05$ & $>0,05$ & $<0,05$ & $<0,05$ \\
\hline
\end{tabular}

Таблиця 5. Вміст загального білка в сироватці крові $\left(r \cdot л^{-1}\right)$ після ендоскопічної і лапароскопічної паліативної декомпресії загальної жовчної протоки при механічній жовтяниці пухлинного генезу, Me (QL; QA) - медіана (нижній і верхній квартилі)

\begin{tabular}{|c|c|c|c|c|c|c|}
\hline \multirow{2}{*}{ Група хворих } & \multirow{2}{*}{$\begin{array}{c}\text { При } \\
\text { госпіталізації }\end{array}$} & \multicolumn{5}{|c|}{ Термін обстеження після операції } \\
\hline & & 1 доба & 7 діб & 14 діб & 3 місяці & 6 місяців \\
\hline $\begin{array}{l}\text { Ендоскопічна } \\
\text { декомпресія }(n=30)\end{array}$ & $\begin{array}{c}60,7 \\
(55,9 ; 63,2)\end{array}$ & $\begin{array}{c}60,5 \\
(58,2 ; \\
63,2)\end{array}$ & $\begin{array}{c}63,4^{*} \\
(59,2 ; \\
68,3)\end{array}$ & $\begin{array}{c}64,2^{*} \\
(60,6 ; \\
69,7)\end{array}$ & $\begin{array}{c}61,9 \\
(58,8 ; 64,3)\end{array}$ & $\begin{array}{c}59,1 \\
(56,7 ; \\
60,6)\end{array}$ \\
\hline \multicolumn{2}{|c|}{$\mathrm{p}_{1}$} & - & 1д & 1д & 14д & 7д,14д,3м \\
\hline $\begin{array}{l}\text { Лапароскопічна } \\
\text { декомпресія }(n=18)\end{array}$ & $\begin{array}{c}60,3 \\
(55,9 ; \\
64,6)\end{array}$ & $\begin{array}{c}59,0 \\
(55,7 ; \\
62,8)\end{array}$ & $\begin{array}{c}65,2^{*} \\
(63,4 ; \\
68,5)\end{array}$ & $\begin{array}{c}66,6^{*} \\
(65,4 ; \\
68,9)\end{array}$ & $\begin{array}{c}68,2^{*} \\
(66,7 ; \\
70,4)\end{array}$ & $\begin{array}{c}67,0^{*} \\
(65,5 ; \\
68,2)\end{array}$ \\
\hline \multicolumn{2}{|c|}{$\mathrm{P}_{2}$} & - & 1д & $1 д$ & 1д,7д,14д & 1д \\
\hline $\mathrm{p}$ & $>0,05$ & $>0,05$ & $>0,05$ & $<0,05$ & $<0,05$ & $<0,05$ \\
\hline
\end{tabular}

яким виконали ендоскопічну декомпресію загальної жовчної протоки, велична показника зменшилася й через 14 діб стала статистично вірогідно меншою, ніж при госпіталізації (на 10,8 \% (p<0,05) та порівняно з 1 добою (на 10,2 \%), p<0,05). В подальшому показник зростав і через 3 і 6 міс. практично не відрізнявся від рівня при госпіталізації ( $>>0,05)$. Крім цього, через 6 міс. показник ставав статистично вірогідно більшим, ніж через 14 діб (на 6,8 \%, p<0,05).

Після проведення ендоскопічної паліативної декомпресії величина індексу INR теж знижувалася, проте показник ставав статистично вірогідно меншим порівняно з рівнем при госпіталізації вже через 7 діб після декомпресії (на 8,7 \%, р<0,05). У подальшому показник постійно знижувався й через 14 діб ставав меншим від рівня при госпіталізації на 12,7 \%, p<0,05), через 3 міс. - на 16,7 \% $(\mathrm{p}<0,05)$, через 6 міс. - на 17,3 \% $(\mathrm{p}<0,05)$. Слід зауважити, що 37 доби до 3 міс. після втручання величина індексу INR у кожен наступний термін спостереження виявилася статистично вірогідно меншою, ніж у попередній $(\mathrm{p}<0,05)$. Починаючи 33 міс. величина досліджуваного показника залишалася стабільною й через 6 міс. істотно не відрізнялася від рівня 3 міс. спостереження ( $>0,05)$.

Порівнюючи дослідні групи між собою, встановили, що через 1, 3 і 14 діб після проведення паліативної декомпресії загальної жовчної протоки істотних відмінностей між групами, в яких виконували ендоскопічне і лапароскопічне втручання, не виявили ( $>00,05)$. Разом $з$ тим, через 3 і 6 міс. показник у групі пацієнтів, яким провели лапароскопічну паліативну декомпресію, був суттєво меншим, порівняно з групою з ендоскопічною декомпресією (відповідно на 10,1 і 12,0%, p<0,05).

Аналіз вмісту в сироватці крові загального білка показав (див. табл. 5), що на тлі ендоскопічної декомпресії показник до 14 діб після втручання підвищувався і був статистично вірогідно більшим, ніж при госпіталізації $(p<0,05)$. Проте через 3 і 6 міс. повертався до рівня, встановленого при госпіталізації (р>0,05). На тлі лапароскопічної декомпресії вміст загального білка в сироватці кро- 
ві теж підвищувався. У всі терміни спостереження показник статистично вірогідно був більшим порівняно з рівнем при госпіталізації ( $<<0,05)$.

Порівняння дослідних груп між собою показало, що, починаючи з 14 доби й через 3 і 6 міс. вміст загального білка в сироватці крові після лапароскопічної декомпресії виявився істотно більшим, ніж після ендоскопічної декомпресії $(\mathrm{p}<0,05)$.

Аналіз динаміки досліджуваного показника у групах пацієнтів, яким застосовували різні методи паліативної декомпресії загальної жовчної протоки, показав, що за умов ендоскопічної декомпресії показник через 7 діб ставав істотно більшим, ніж через одну добу ( $<<0,05)$, залишався на такому ж рівні до 14 доби спостереження ( $>>0,05)$. Через 3 міс. показник знижувався і через 6 міс. ставав істотно меншим, ніж через 7, 14 діб і 3 міс. спостереження $(\mathrm{p}<0,05)$.

У групі пацієнтів, яким виконували лапароскопічну декомпресію показник до 3 міс. спостереження поступово зростав, досягав максимальної величини й статистично вірогідно перевищував попередні терміни спостереження $(\mathrm{p}<0,05)$.

Через 6 міс. спостерігали зменшення вісту в сироватці крові загального білка, проте його величина продовжувала залишатися істотно більшою, ніж через одну добу після операції.

У свою чергу, вміст у сироватці крові альбумінів (табл. 6) на тлі ендоскопічної декомпресії протягом 7 діб після втручання практично не відрізнявся від рівня при госпіталізації (p>0,05). Проте через 14 діб показник суттєво підвищувався і ставав статистично вірогідно більшим, ніж при госпіталізації (p<0,05). Аналогічно більшим, порівняно $з$ терміном при госпіталізації, він виявився й через 3 міс. $(\mathrm{p}<0,05)$. Через 6 міс. вміст альбумінів у сироватці крові знижувався, й показник практично не відрізнявся від рівня при госпіталізації $(\mathrm{p}<0,05)$.
Після лапароскопічної декомпресії вміст альбумінів у сироватці крові вже через 7 діб після операції ставав статистично вірогідно більшим, ніж при госпіталізації $(\mathrm{p}<0,05)$ і продовжував суттєво перевищувати цей рівень в інші терміни спостереження $(\mathrm{p}<0,05)$.

Порівняння дослідних груп показало, що через 7 діб, а також через 3 і 6 міс. після втручання на тлі лапароскопічної декомпресії вміст у сироватці крові альбумінів був статистично вірогідно більшим, ніж після ендоскопічної декомпресії $(\mathrm{p}<0,05)$.

Аналіз динаміки вмісту альбумінів у сироватці крові показав, що за умов ендоскопічної декомпресії показник до 14 доби спостереження зростав і в цей термін виявився суттєво більшим, ніж у попередні терміни спостереження $(\mathrm{p}<0,05)$. У наступні терміни показник знижувався й через 6 міс. був статистично вірогідно меншим, ніж через 14 діб і 3 міс. після втручання $(\mathrm{p}<0,05)$.

На тлі лапароскопічної декомпресії вміст у сироватці крові альбумінів через 7 діб спостереження суттєво зростав порівняно з першою добою ( $<0,05)$. Через 14 діб показник продовжував зростати й досягав максимуму, істотно перевищуючи 1 i 7 доби спостереження $(\mathrm{p}<0,05)$. На такому ж рівні показник знаходився й через 3 і 6 міс. спостереження ( $>0,05)$.

Таким чином, застосування з паліативною метою ендоскопічної і лапароскопічної декомпресії до 14 діб призводить до статистично вірогідного зниження протромбінового часу, індексу INR і збільшення вмісту в сироватці крові загального білка та альбумінів порівняно з рівнем при госпіталізації. У подальшому після застосування ендоскопічного втручання величина протромбінового часу та величина індексу INR починають зростати, а вміст загального білка і альбумінів у

Таблиця 6. Вміст альбумінів у сироватці крові $\left(\left\ulcorner\cdot л^{-1}\right)\right.$ після ендоскопічної і лапароскопічної паліативної декомпресії загальної жовчної протоки при механічній жовтяниці пухлинного генезу, Me (QL; QA) - медіана (нижній і верхній квартилі)

\begin{tabular}{|c|c|c|c|c|c|c|}
\hline \multirow{2}{*}{ Група хворих } & \multirow{2}{*}{$\begin{array}{c}\text { При } \\
\text { госпіталізації }\end{array}$} & \multicolumn{5}{|c|}{ Термін обстеження після операції } \\
\hline & & 1 доба & 7 діб & 14 діб & 3 місяці & 6 місяців \\
\hline $\begin{array}{l}\text { Ендоскопічна } \\
\text { декомпресія }(\mathrm{n}=30)\end{array}$ & $\begin{array}{c}33,1 \\
(30,8 ; \\
34,7)\end{array}$ & $\begin{array}{c}32,8 \\
(31,1 ; \\
34,7)\end{array}$ & $\begin{array}{c}34,2 \\
(32,2 ; \\
36,4)\end{array}$ & $\begin{array}{c}37,2^{*} \\
(35,9 ; \\
39,6)\end{array}$ & $\begin{array}{c}36,2^{*} \\
(33,4 ; \\
37,6)\end{array}$ & $\begin{array}{c}33,6 \\
(32,2 ; \\
35,4)\end{array}$ \\
\hline \multicolumn{2}{|c|}{$\mathrm{p}_{1}$} & - & - & 1 1д,7д & 1 д, 7 д & $14 д, 3 \mathrm{M}$ \\
\hline $\begin{array}{l}\text { Лапароскопічна } \\
\text { декомпресія }(n=18)\end{array}$ & $\begin{array}{c}34,2 \\
(31,7 ; \\
36,6)\end{array}$ & $\begin{array}{c}31,9 \\
(30,1 ; \\
34,0)\end{array}$ & $\begin{array}{c}36,4^{*} \\
(35,3 ; \\
38,0)\end{array}$ & $\begin{array}{c}38,0^{*} \\
(36,9 ; \\
39,4)\end{array}$ & $\begin{array}{c}39,9^{*} \\
(38,9 ; \\
41,1)\end{array}$ & $\begin{array}{c}38,0^{*} \\
(37,1 ; \\
38,4)\end{array}$ \\
\hline \multicolumn{2}{|c|}{$\mathrm{p}_{2}$} & - & 1 1д & 1 1д,7д & 1 1д,7д,14д & 1д \\
\hline$p$ & $>0,05$ & $>0,05$ & $<0,05$ & $>0,05$ & $<0,05$ & $<0,05$ \\
\hline
\end{tabular}


сироватці крові знижуватися, що стає суттєвим порівняно з попередніми термінами спостереження. Після лапароскопічного втручання показники продовжують покращуватися й через 3-6 міс. статистично вірогідно відрізняються від аналогічних, отриманих при ендоскопічному втручанні.

Отримані результати свідчать, що лапароскопічна декомпресія створює більші фізіологічні умови для відтоку жовчі, ніж ендоскопічна декомпресія. Холедохоєюноанастомоз меншою мірою піддається впливу онкопроцесу, що забезпечує протягом 6 міс. сталий відтік жовчі і знижує прояви печінкової недостатності. Водночас на тлі ендоскопічної декомпресії через 3-6 міс. після втручання у 9 пацієнтів $(30,0 \pm 8,4)$ \% спостерігали ускладнення у вигляді рефлюкс-холангіту, холангіогенних абсцесів і появи повторних епізодів жовтяниць, які, очевидно, стали основною причиною поглиблення порушень показників гепатодепресивного синодрому.

Таким чином, лапароскопічний спосіб декомпресії загальної жовчної протоки за умов нерезектабельних періампулярних пухлин, при технічно грамотному виконанні $є$ гідною альтернативою традиційним ендоскопічним методам, забезпечує сталий відтік жовчі, супроводжується меншими проявами гепатодепресивного синдрому.

\section{СПИСОК ЛІТЕРАТУРИ}

1. Ishihara S. Epidemiology of biliary tract cancer - comparison with other country / S. Ishihara, A. Horiguchi // Nihon Rinsho. 2015. - Vol. 73 (Suppl. 3). - P. 466-470.

2. Morine Y. Nation wide survey of pancreaticobiliary maljunction / Y. Morine, M. Shimada, H. Ishibashi // Nihon Shokakibyo Gakkai Zasshi. - 2014. -Vol. 111, No 4. - P. 699-705.

3. Cartwright T. Cancer of the pancreas: are we making progress? A review of studies in the US Oncology Research Network / T. Cartwright, D. A. Richards, K. A. Boehm // Cancer Control. 2008. - Vol. 15, No. 4. - Vol. 308-313.

4. Japan Pancreatic Cancer Registry; 30th year anniversary: Japan Pancreas Society / S. Egawa, H. Toma, H. [et al.] // Pancreas. 2012. - Vol. 41, No. 7. - P 985-992.

5. Risk factors of morbidity and predictors of long-term survival after hepatopancreatoduodenectomy for biliary cancer / M. Utsumi, H. Sadamori, S. Shinoura [et al.] // Hepatogastroenterology. - 2014. - Vol. 61, No. 136. - P. 21672172.

\section{REFERENCES}

1. Ishihara, S. \& Horiguchi, A. (2015). Epidemiology of biliary tract cancer - comparison with other country. Nihon Rinsho, 73, (3), 466-470.

2. Morine, Y, Shimada, M. \& Ishibashi, H. (2014). Nation wide survey of pancreaticobiliary maljunction. Nihon Shokakibyo Gakkai Zasshi, 111 (4), 699-705.

3. Cartwright, T., Richards, D.A. \& Boehm, K.A. (2008). Cancer of the pancreas: are we making progress? A review of studies in the US Oncology Research Network. Cancer Control, 15 (4), 308-313.
Висновки. 1. Лапароскопічна декомпресія загальної жовчної протоки шляхом формування гепатикоєюноанастомозу порівняно з ендоскопічними методами у хворих із неоперабельними періампулярними пухлинами супроводжується швидшим відновленням функціонального стану печінки, що проявляється сталим зниженням протромбінового часу, індексу INR і збільшенням вмісту в сироватці крові загального білка та альбумінів через 3-6 міс. після декомпресії.

2. На тлі ендоскопічної декомпресії в цей період протромбіновий час та індекс INR статистично вірогідно більші, вміст у сироватці крові загального білка і альбумінів - менші, порівняно з лапароскопічною декомпресією.

3. Через 6 міс. після втручання за умов ендоскопічної декомпресії показники гепатодепресивного синдрому суттєво погіршуються, що пов'язано 3 розвитком у 30 \% пацієнтів ускладнень.

Перспективи подальших досліджень. Отримані результати націлюють на подальші дослідження щодо клінічного обгрунтування ширшого впровадження лапароскопічного методу декомпресії загальної жовчної протоки у хворих із неоперабельними періампулярними пухлинами.

6. Малярчук В. И. Билиопанкреатодуоденальный рак. / В. И. Малярчук, А. Е. Климов, Ю. Ф. Пауткин. - М. : Рос. ун-т дружбы народов, 2009. - 444 с.

7. Rerknimitr R. Operable malignant jaundice: To stent or not to stent before the operation? / R. Rerknimitr, P. Kullavanijaya // World J. Gastrointest. Endosc. - 2010. - Vol. 2, No. 1. - P. 10-14. 8. Ендоскопічні транспапілярні методи лікування холедохолітіазу, спричиненого множинними конкрементами / П. В. Огородник, А. Г. Дейниченко, Д. І. Христюк, О. Г. Бойко // Клін. хірургія. - 2012. - № 1. - С. 10-13.

9. Огородник П. В. Ендоскопічна хірургія дистальної оклюзії загальної жовчної протоки / П. В. Огородник, А. Г. Дейниченко, О. Г. Бойко // Укр. журн. малоінвазив. та ендоскоп. хірургії. - 2014. - Т. 18, № 4. - С. 19-22.

10. Лапароскопічна гепатикоєюностомія в лікуванні іктерогенних пухлин періампулярної зони / М. Ю. Ничитайло, О. П. Кондратюк, Ю. О. Хілько [та ін.] // Шпитальна хірургія. Журнал імені Л. Я. Ковальчука. - 2016. - № 2. - С. 5-9.

4. Egawa, S., Toma, H., Ohigashi, H., Okusaka, T., Nakao, A. \& Hatori, T. (2012). Japan Pancreatic Cancer Registry; 30th year anniversary: Japan Pancreas Society. Pancreas, 41 (7), 985-992. 5. Utsumi, M., Sadamori, H., Shinoura, S., Umeda, Y., Yoshida, R. \& Nobuoka, D. (2014). Risk factors of morbidity and predictors of long-term survival after hepatopancreatoduodenectomy for biliary cancer. Hepatogastroenterology, 61 (136), 2167-2172.

6. Malyarchuk, V.I., Klimov, A.E. \& Pautkin, Yu.F. (2009). Biliopankreatoduodenalnyy rak [Biliopancreatoduodenal 
cancer]. Moscow: Ros. un-t druzhby narodov [in Russian].

7. Rerknimitr, R. \& Kullavanijaya, P. (2010). Operable malignant jaundice: To stent or not to stent before the operation? World J. Gastrointest. Endosc., 2 (1), 10-14.

8. Ohorodnyk, P.V., Deinychenko, A.H., Khrystiuk, D.I. \& Boyko, O.H. (2012). Endoskopichni transpapiliarni metody likuvannia kholedokholitiazu, sprychynenoho mnozhynnymy konkrementamy [Endoscopic transpacillary methods of treatment of choledocholithiasis induced by multiple concrements]. Klin. Khirurhiia - Clin Surgery, 1, 10-13 [in Ukrainian].

9. Ohorodnyk, P.V., Deinychenko, A.H. \& Boiko, O.H. (2014). Endoskopichna khirurhiia dystalnoi okliuzii zahalnoi zhovchnoi protoky [Endoscopic surgery for distal occlusion of the common bile duct]. Ukr. zhurn. maloinvazyv. ta endosk. Khirurhii - Ukrainian Journal of Small Invasive Endoscopic Surgery, 18 (4), 19-22 [in Ukrainian]. 10. Nychytailo, M.Yu., Kondratiuk, O.P., Khilko, Yu.O., Ohorodnik, P.V., Shkarban, V.P. \& Kondratiuk, V.A. (2016). Laparoskopichna hepatykoieiunostomiia v likuvanni ikterohennykh pukhlyn periampuliarnoi zony [Laparoscopic hepaticoinostomy in the treatment of itekogenic tumors of the periampulsion zone]. Shpytalna khirurhiia. Zhurnal imeni L.Ya. Kovalchuka-L.Ya. Kovalchuk Journal of Hospital Surgery, 2, 5-9 [in Ukrainian].

Електронна адреса для листування: adeyn@ukr.net

M. Y. NYCHITAYLO, O. P. KONDRATIUK, YU. O. KHILKO, P. V. OGORODNYK, A. G. DEINYCHENKO, V. A. KONDRATIUK, N. A. YERMAK, T. A. YUSUPOV

O. Shalimov National Institute of Surgery and Transplantation

\title{
DYNAMICS OF PARAMETERS OF HEPATODEPRESSIVE SYNDROME IN PATIENTS WITH MECHANICAL JAUNDICE OF TUMOUR GENESIS AFTER ENDOSCOPIC AND LAPAROSCOPIC PALIATIVE DECOMPRESSION OF COMMON BILE DUCT
}

\begin{abstract}
The aim of the work: to find out the dynamics of indicators of hepatodepressive syndrome in patients with mechanical jaundice of tumor genesis after endoscopic and laparoscopic palliative decompression of the common bile duct.

Materials and Methods. Under observation, between 2011 and 2017 there were 48 patients who, as a result of a comprehensive examination, found incurable tumors against a background of severe mechanical jaundice. All patients underwent palliative decompression of the common bile duct: 30 patients - using endoscopic methods; 18 patients - using laparoscopic hepaticojejunostomy. Each subgroup was randomized according to age, sex, duration of the jaundice, and the basic biochemical parameters identified before surgery. Patients were observed for 6 months after decompression. Before surgery, as well as 1, 7 and 14 days, as well as 3 and 6 months in patients, the markers of hepatodepressive syndrome: prothrombin time, total protein and serum albumin values were determined according to well-known methods.

Results and Discussion. Laparoscopic decompression of the common bile duct by forming hepaticojejunostomy in comparison with endoscopic methods is accompanied by a rapid restoration of the functional state of the liver, which is manifested by a constant decrease in prothrombin time of INR and an increase in serum total protein and albumin contents in 3-6 months after decompression. On the background of endoscopic decompression in this period, the prothrombin time and the INRs are statistically significantly higher, the serum total protein and albumin content is lower compared to laparoscopic decompression. 3-6 months after intervention under endoscopic decompression, hepatodepressive symptoms are significantly deteriorating, which is associated with the development of $30 \%$ of patients with complications.
\end{abstract}

Key words: laparoscopic hepaticojejunostomy; mechanical jaundice; periampullary tumor; hepatodepressive syndrome.

М. Е. НИЧИТАЙЛО, А. П. КОНДРАТЮК, Ю. А. ХИЛЬКО, П. В. ОГОРОДНИК, А. Г. ДЕЙНИЧЕНКО, В. А. КОНДРАТЮК, Н. А. ЕРМАК, Т. А. ЮСУПОВ

ГУ “Национальный институт хирургии и трансплантологии имени А. А. Шалимова"

\section{ДИНАМИКА ПОКАЗАТЕЛЕЙ ГЕПАТОДЕПРЕССИВНОГО СИНДРОМА У БОЛЬНЫХ С МЕХАНИЧЕСКОЙ ЖЕЛТУХОЙ ОПУХОЛЕВОГО ГЕНЕЗА ПОС.ЛЕ ЭНДОСКОПИЧЕСКОЙ И ЛАПАРОСКОПИЧЕСКОЙ ПАЛЛИАТИВНОЙ ДЕКОМПРЕССИИ ОБЩЕГО ЖЕЛЧНОГО ПРОТОКА}

Цель работы: выяснить динамику показателей гепатодепрессивного синдрома у больных с механической желтухой опухолевого генеза после эндоскопической и лапароскопической паллиативной декомпрессии общего желчного протока. Материалы и методы. Под наблюдением в период с 2011 по 2017 г. находилось 48 пациентов, у которых в результате комплексного обследования обнаружили инкурабельные опухоли на фоне выраженной механической желтухи. Всем больным 


\section{З ДОСВІДУ РОБОТИ}

выполнена паллиативная декомпрессия общего желчного протока: 30 пациентов - с применением эндоскопических методов; 18 пациентов - с использованием лапароскопической гепатикоеюностомии. Каждую подгруппу рандомизировали по возрасту, полу, длительности желтушного периода и основным биохимическим показателям, определенными до операции. Пациентов наблюдали в течение 6 мес. после декомпрессии. До операции, а через 1, 7 и 14 суток, а также 3 и 6 мес. у пациентов определяли маркеры гепатодепрессивного синдрома: протромбиновое время, содержание общего белка и альбумина в сыворотке крови по общеизвестным методам.

Результаты исследований и их обсуждение. Лапароскопическая декомпрессия общего желчного протока путем формирования гепатикоеюноанастомоза по сравнению с эндоскопическими методами сопровождается быстрым восстановлением функционального состояния печени, проявляется постоянным снижением протромбинового времени, индекса INR и увеличением содержания в сыворотке крови общего белка и альбумина через 3-6 месяцев после декомпрессии. На фоне эндоскопической декомпрессии в этот период протромбиновое время и индекс INR статистически достоверно больше, содержание в сыворотке крови общего белка и альбумина - меньше, по сравнению с лапароскопической декомпрессией. Через 3-6 мес. после вмешательства в условиях эндоскопической декомпрессии показатели гепатодепресивного синдрома существенно ухудшаются, что связано с развитием в 30 \% пациентов осложнений.

Ключевые слова: лапароскопический гепатикоеюноанастомоз; механическая желтуха; периампулярна опухоль; гепатодепрессивний синдром. 